Vol. VII, Fasc. 1 e 2, p. $81-86$.

\title{
A NEW POLYCLAD FROM BRAZIL
}

(Received 19-9-957)

\section{Diva Diniz Corrêa}

(Caixa Postal 6994, S. Paulo)

(with one plate)

During a collecting trip to Cabo Frio (Lat. $22^{\circ} 57^{\prime} \mathrm{S}$.; Long. $42^{\circ} 1^{\prime}$ W.) in July 1957, subsidized by the National Research Council (Conselho Nacional de Pesquisas, Rio de Janeiro), I found a triclad-shaped Turbellarian which belongs to the Chromoplanidae Bock (1922, p. 29).

The locality of its occurrence is a tide-pool on a very exposed rocky coast, the "práia do Forte". The depth of this pool is about $1 \mathrm{~m}$ at low tide; its water was clean and cool in the winter month when I collected there several times. There were many stones on the bottom of the tide-pool and under one of them the Chromoplanid was found.

The biotope contained Padina, with many Amphipods, and on and under the stones, small sponges (Sycon), Entoprocta (Barentsia discreta Busk), several Polycladida (e. g. species of Pseudoceros and Enchiridium) Polyplacophora, Brachiopods and Echinoderms.

The species of the Chromoplanidae is new and constitutes the type of a new genus.

\section{Chromyella, new genus.}

Chromoplanidae with or l, male and female apertures united; male copulatory apparatus constituted by spermiducal vesicle, seminal vesicle and penial organ; without prostatic vesicle.

Type of the genus: Chromyella saga, new species.

The two known species of Chromoplanidae were found in the Sagami Bay (Bock 1922, p. 1) and about $400 \mathrm{kms}$ farther South, near Seto, Wakayama Prefecture (Kato 1938, p. 588). They represent the genera Chromoplana Bock (1922, p. 1) and Amyella Bock (1922, p. 20). 
In these two genera, the marginal eyes are less numerous than in Chromyella and the mouth is situated anteriorly to the male pore. In Amyella, the two genital pores lie close together, and the prostatic vesicle is reduced to a canal which pierces the penis. Chromoplana has the same longitudinal fold and an unpaired spermiducal vesicle as the new genus. Chromyella differs from both genera, though it has characters in common with either of them.

\section{Chromyella saga, new species}

(Figs. 1-4)

The live worm is anteriorly widened and tapers gradually backwards. The fore and hind ends are pointed. After preservation the worm became elliptical (Figs. 1, 3) with both ends rounded. Antero-dorsally it has two broad pigmented, almost black, spots with irregular borders (Figs. 1-2, $n$ ). On the back there are two wide stripes, also with irregular outlines, of a deep brown colour (Figs. 1-2, $l$ ). The pigmented stripes fuse posteriorly and touch the anterior spots. The ground colour as well as the ventral side are whitish. The pigment persisted after fixation with warm Susa.

The length of the live worm is $8 \mathrm{~mm}$ and the maximum breadth $1,5 \mathrm{~mm}$. Preserved it measures 6 and $1 \mathrm{~mm}$. Between the two anterior pigmented spots is a light zone corresponding to the cerebral region. Here there are two rows of cerebral eyes (Figs. 1-2, c). Each row has 8 eyes, of which 7 on the right side and 5 on the left are double. On the antero-lateral borders there are two very distinct series of marginal eyes (Figs. 1-2, i). Each series has about 13 groups of eyes, some contain single, others 2-5 eyes. The pigment of the eyes is preserved after fixation. The biggest cerebral eye measures 50 microns in maximum diameter and the biggest marginal ones, 25 microns. The eyes are situated in the parenchyma a little distant from the epidermis; they are visible also from the ventral side of the body. There is a sensory, transverse, anterior, deep furrow (Figs. 1-2, $r$ ) and a longitudinal, ventro-median, fold extending from the brain to the oral aperture. The sucker was not seen either in the total worm or in the sections. The worm had a wound in the region of its probable localization.

The epidermis is relatively high. It has many glands with granular aspect and numerous rhabdites. These are found in rhabditogenous cells, forming bundles of several elements. Many of them are discharged and appear as filaments outside the epidermis. There are numerous basophilous, sub-cutaneous glands with variable dimensions, whose outlets can be followed through the epidermis. The basement membrane is well developed. The cutaneous muscles are distinct only in the anterior third of the body. The pigment of the anterior spots and the longitudinal stripes is situated immediately beneath the epidermis. The parenchyma is richly developed. 
The small mouth (Figs. 3-4, t) lies in the posterior third of the pharynx (a); from behind, the male (Fig. 4,o) and female pore open into the oral tube. The pharynx $(a)$ is large and rather folded. The principal gut $(f)$ and the intestinal diverticles contain plenty of food in the lumen and show phases of extra- and intra-cellular digestion.

The testes (Fig. 3, $x$ ) are situated near the ventral surface; they occupy a wide stripe from the anterior limit of the pharynx $(a)$ to the last sixth of the body. The testes were in various stages of spermatogenesis. The male copulatory apparatus (Figs. 3-4) lies ventrally and is directed forwards. The large unpaired spermiducal vesicle $(s)$ is higher than broad; its walls are thin and it contains masses of sperm (Fig. $4, w)$. This vesicle $(s)$ is united to the true seminal vesicle $(v)$ by a short canal. The seminal vesicle is larger than the spermiducal vesicle; it is longish and directed slightly upwards. It has a thick muscular wall and lodges a large amount of sperm $(w)$. The ejaculatory duct $(e)$ leaves the seminal vesicle $(v)$ in front; it is also coated with muscles. The ental part of this duct is slightly dilated and perhaps corresponds to the tubiform prostatic (granule) vesicle of Amyella lineata Bock (1922, p. 26 t. 1 f. 5). Around the ejaculatory duct (e) there are two types of glands. They differ by the intensity of their coloration, localization and place of their openings. The first more intensely colored type $(g)$ is less numerous; the glandular bodies are situated perpendicular to the ental part of the ejaculatory duct $(e)$ and open in this region. The second more numerous type $(u)$ is less strongly colored. Its glandular bodies form a mass situated from the ectal part of the seminal vesicle $(v)$ to the tip of the penial papilla $(p)$. These glands are directed towards the ectal part of the ejaculatory duct where they open. The penis $(p)$ is large, unarmed, and has thick muscles. Ectally to the penis the long male antrum $(m)$ lies under the hind end of the pharynx $(a)$; it is slightly curved and almost without muscles. The antrum forms a narrow slit around the penial papilla $(p)$.

To judge from the well developed testes and the absence of traces of ovaries, the worm is pronouncedly protandrous. The female apparatus (Fig. 4) is still very simple; it is situated ventrally to the male apparatus. It is composed of a small ental vesicle (b), on the same level as the spermiducal vesicle $(s)$. From this ental female vesicle a long, narrow, uniform vagina $(d)$ with extremely low walls goes out. Its course, slightly inclined to the ventral surface, is well visible to the proximity of the ectal part of the male antrum $(m)$. I did not find special glands around the female duct, probably as a consequence of the very young state of the total female apparatus of the only present specimen. The terminal part of the vagina was not seen. However I infer from the visible part that the female opening must lie ventrally to the male gonopore $(o)$ or possibly in the outer part of the male antrum $(m)$. 


\section{R E S U M O}

Um Policladido, Chromyella saga, gen. nov., spec. nov. (Figs. 1-4) das Chromoplanidae Bock (1922, p. 29), foi encontrado num "tidepool", da práia do Forte, em Cabo Frio. Caracteriza-se pela união dos orifícios bucal, masculino e feminino (Fig. 4), aparelho copulador masculino composto por vesícula espermiducal ímpar $(s)$, vesicula seminal $(v)$ e ausência de vesícula prostática.

As duas espécies conhecidas das Chromoplanidae, representantes dos gêneros Chromoplana e Amyella Bock 1922, proveem do Japão. Nos dois gêneros japoneses os olhos marginais são menos numerosos que em Chromyella e a bôca situa-se anteriormente ao orifício masculino. Em Chromoplana ocorre vesicula espermiducal ímpar e sulco longitudinal. Em Amyella os dois poros genitais acham-se muito próximos entre si e a vesícula prostática é reduzida a um canal que atravessa o penis. Chromyella, além de diferir de Chromoplana e Amyella, apresenta caracteres peculiares a cada um dêles.

\section{REFER E N E S}

BOCK, S., - 1922. Two new Cotylean genera of Polyclads from Japan and remarks on some other Cotyleans. Ark. Zool. v. 14 n. 13, p. 1-31 t. 1-2. Stockholm.

KATO, K., - 1938. Polyclads from Seto, Middle Japan. Japan. Journ. Zool. 7, p. 577-593 t. 38-39. Tokyo. 

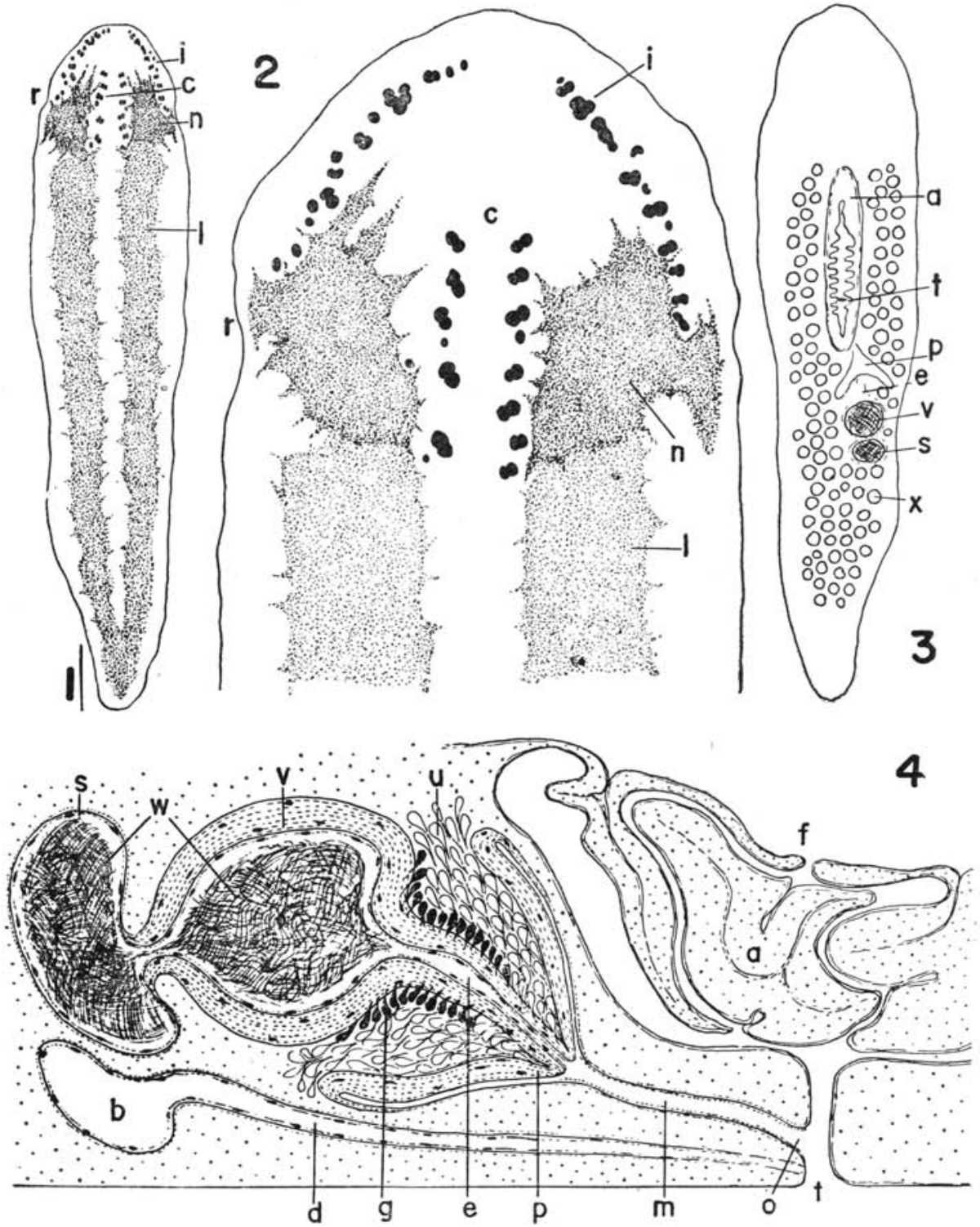


\section{PLA T E 1}

Chromyella saga, new genus, new species.

Fig. 1 - Total, dorsal view of clarified worm.

Fig. 2 - Antero-dorsal part of body.

Fig. 3 - Total, ventral view of clarified worm.

Fig. 4 - Diagram of copulatory apparatus (reconstructed).

$a$ - pharynx. $b$ - female vesicle. $c$ - cerebral eyes. $d$ - female duct (vagina). $e-$ ejaculatory duct. $f-$ main intestine. $g-$ granule (prostatic) glands. $i$ - marginal eyes. $l$ - longitudinal pigmented stripes. $m-$ male antrum. $n$ - anterior pigmented spots. o - male gonopore. $p$ - penis papilla. $r$ - sensory transverse furrow. $s-$ spermiducal vesicle. $t-$ mouth. $u-$ cyanophilous glands. $v-$ seminal vesicle. $w-$ sperm. $x$ - testes. 